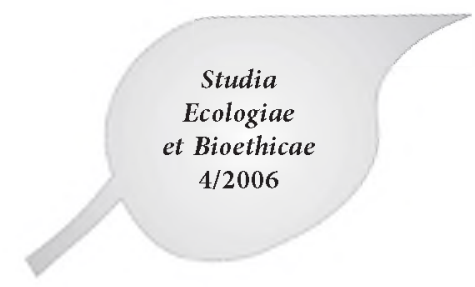

Grażyna NOWICKA

IEiB UKSW Warszawa

\title{
Białka roślinne i ich funkcjonalne działania
}

\section{Wprowadzenie}

Żywienie jest czynnikiem o kluczowym znaczeniu dla rozwoju i działania organizmu. W myśl tradycyjnego podejścia do żywienia codzienna dieta powinna dostarczać odpowiedniej ilości składników odżywczych w celu zapewnienia prawidłowego przebiegu procesów metabolicznych i utrzymania zdrowia. Aktualnie powszechnie akceptowanym jest pogląd, że zarówno sposób żywienia jak i jakość zdrowotna spożywanej żywności w istotny sposób mogą warunkować występowanie wielu chorób przyspieszając lub opóźniając ich rozwój. Wyodrębniono dużą grupę chorób określanych mianem dietozależnych. W grupie tej szczególne miejsce zajmują choroby występujące $\mathrm{z}$ duża częstością, wśród których kluczowe miejsce zajmują: choroba niedokrwienna serca, nadciśnienie tętnicze, otyłość, cukrzyca.

Liczne badania epidemiologiczne, kliniczne i doświadczalne pokazują, że pewne składniki pożywienia w istotny sposób wpływają na różne procesy zachodzące $w$ organizmie, a efektem ich działania jest uzyskanie określonych korzyści zdrowotnych.

\section{Koncepcja żywności funkcjonalnej}

Obecnie panuje pogląd, że odpowiednio skomponowana dieta nie tylko stanowi podstawę dla prawidłowego rozwoju i działania organizmu, ale może pomagać w osiągnięciu lepszego stanu zdrowia i obniżać ryzyko rozwoju wielu chorób. Gremia naukowe formułują zalecenia dotyczące składu diety, zwracają uwagę na konieczność spożywania określonych produktów zapewniających dowóz odpowiednich składników. W celu umożliwienia jednostkom/grupom skomponowanie codziennej diety o optymalnym składzie zapewniającym zachowanie zdrowia i obniżenie ryzyka wystąpienia chorób przewlekłych, zaczęto rozwijać koncepcję żywności funkcjonalnej. 
Żywność określana mianem funkcjonalnej musi wpływać na procesy, które w istotny sposób wpływają na obniżenie ryzyka rozwoju określonych chorób i których modulacja pozwala na poprawę stanu zdrowia (10). Wpływ ten musi być udokumentowany w oparciu o wskaźniki jednoznacznie odnoszące się do procesów będących przedmiotem zainteresowania, ukazywać ich modulacje oraz efekty tych działań. Można posługiwać się tylko wskaźnikami o istotnym znaczeniu biologicznym, uznanymi za specyficzne, czułe i powtarzalne. Muszą one bezpośrednio odnosić się do badanego procesu, jego zmiany lub biologicznej odpowiedzi na tę zmianę. Używane wskaźniki powinny określać zarówno krótko-terminowy jak i długo-terminowy wpływ żywności lub składnika żywności, któremu przypisujemy to szczególne działanie. Funkcjonalne działanie żywności musi być określone i udokumentowane w oparciu o badania żywieniowe i odnosić się bądź do wszystkich członków danej populacji lub ściśle zdefiniowanych grup, które mogą/powinny spożywać tę żywność. Należy również zdefiniować, jaka ilość produktu/składnika spożywana jako element codziennej diety wywoluje pozytywny efekt zdrowotny.

Do produktów, których spożywanie wiąże się ze zmniejszaniem ryzyka wystąpienia choroby niedokrwiennej serca należą nasiona roślin strączkowych. Z obserwacji epidemiologicznych wynika, że w krajach o wysokim spożyciu nasion roślin strączkowych, zapadalność na chorobę niedokrwienna serca (ChNS) jest niska. Wykazano, że zawarte w nasionach tych roślin białka, błonnik pokarmowy, witaminy, związki o właściwościach antyoksydacyjnych, fitosterole, a także kwasy tłuszczowe są czynnikami odgrywającymi ważną rolę w prewencji nie tylko ChNS lecz także cukrzycy i wielu chorób nowotworowych. W ostatnich latach szczególną uwagę zwrócono na białka nasion jadalnych roślin strączkowych (3).

\section{Białka organizmu a białka pokarmowe}

Białka są kluczowym, strukturalnym i funkcjonalnym składnikiem organizmu człowieka. Synteza białek ustrojowych wymaga dostępności odpowiednich aminokwasów. Głównym źródłem tych aminokwasów jest dieta, chociaż część $\mathrm{z}$ nich (tzw. aminokwasy endogenne) może być syntetyzowana $\mathrm{w}$ organizmie człowieka z elementów pochodzących z przemian węglowodanów i kwasów tłuszczowych. Część aminokwasów (tzw. aminokwasy egzogenne) musi być bezwzględnie dostarczona z pożywieniem, gdyż organizm człowieka nie potrafi ich syntetyzować.

Ze względu na rolę aminokwasów dostarczanych $\mathrm{z}$ dietą w metabolizmie białek ustrojowych, białko pokarmowe należy obok tłuszczy i węglowodanów do głównych składników diety. Prawidłowy rozwój i działanie organizmu wymaga dowozu białka na odpowiednim poziomie. Udział białka w energetycznej wartości diety określone jest na poziomie między $10 \%$ a $20 \%$. 
Obecny stan wiedzy jednoznacznie pokazuje, że pełne pokrycie zapotrzebowania organizmu człowieka na aminokwasy wymaga dostarczania z pożywieniem nie tylko odpowiedniej ilości aminokwasów niezbędnych (egzogennych), ale także wszystkich pozostałych aminokwasów. W organizmie człowieka preferowanymi substratami do syntezy aminokwasów endogennych są bowiem $\alpha$ aminowe szkielety pochodzące $\mathrm{z}$ aminokwasów pożywienia. Obecność w pożywieniu odpowiedniej ilości aminokwasów takich jak np. alanina, kwas asparaginowy czy kwas glutaminowy, zapewnia dostępność szkieletów a-aminowych, a w efekcie zabezpiecza wymagany poziom syntezy aminokwasów i białek.

$\mathrm{Z}$ punktu widzenia zachowania zdrowia konieczne jest nie tylko dostarczanie z pożywieniem odpowiedniej ilości białka, ale także dostarczanie białka pochodzącego z różnych źródeł. Białka zwierzęce mają co prawda wyższą wartość odżywczą, tzn. dostarczają odpowiednią ilość wszystkich niezbędnych aminokwasów, ale badania pokazują, że białka roślinne wywierają korzystne działania metaboliczne.

\section{Hipolipemiczne działanie białka nasion roślin strączkowych}

Meta-analiza wyników 38 badań klinicznych (1), w których pacjentom z zaburzeniami lipidowymi zalecano zastąpienie białka zwierzęcego białkiem sojowym wykazała istotny spadek stężenia cholesterolu całkowitego, cholesterolu lipoprotein o niskiej gęstości (LDL), triglicerydów oraz wzrost cholesterolu lipoprotein o wysokiej gęstości (HDL). Stwierdzono, że regularne spożywanie białka sojowego w ilości 30-50g dziennie skutkuje spadkiem stężenia cholesterolu całkowitego średnio o $9.3 \%$, cholesterolu LDL o 12,3\%, triglicerydów o 10,5\% oraz wzrost stężenia cholesterolu HDL o 2,4\%. Hipolipemiczne działanie białka soi okazało się być wprost proporcjonalne do wyjściowego stężenia cholesterolu we krwi badanych osób. Zmiany w stężeniu badanych lipidów we krwi były niezależne od spożycia tłuszczu i cholesterolu.

Analiza wyników badań klinicznych $(2,11,12)$, w których osobom z zaburzeniami gospodarki lipidowej podawano w diecie białko innych niż soja roślin strączkowych: grochu, fasoli, słodkich odmiana łubinu wykazała że zastąpienie $\mathrm{w}$ diecie białka zwierzęcego białkiem roślinnym powoduje u badanych osób istotne obniżenie cholesterolu całkowitego o 7,2\%, LDL-cholesterolu o 6,2\%, triglicerydów o $16,6 \%$ oraz nieistotny wzrost HDL-cholesterolu o 2,6\%. Ten hipolipemiczny efekt był szczególnie widoczny u osób z początkowym stężeniem cholesterolu całkowitego we krwi powyżej $240 \mathrm{mg} / \mathrm{dl}$. Podawanie grochu konserwowanego przez okres 3-tygodni pacjentom $\mathrm{z}$ początkowym stężeniem cholesterolu powyżej $300 \mathrm{mg} / \mathrm{dl}$ wywoływało spadek jego stężenia średnio o $18 \%$ w tym o $23 \%$ we frakcji LDL. W innych badaniach kobiet o początkowym stężeniu cholesterolu poniżej $230 \mathrm{mg} / \mathrm{dl}$, które przez 4 miesiące spożywały w codziennej diecie około 140g grochu, spadek stężenia cholesterolu całkowitego i LDL-chole- 
sterolu wynosił 7\%, a triglicerydów dochodził do 25\%, a w wypadku spożywania mąki z grochu obniżenie triglicerydów we krwi wynosiło $36 \%$.

Specyficzne hipolipemiczne działanie białka nasion roślin strączkowych związane jest $\mathrm{z}$ uwalnianiem $\mathrm{w}$ procesie trawienia niskocząsteczkowych peptydów, które wpływają na regulację wewnątrzkomórkowego metabolizmu cholesterolu $(8,9)$. Analiza białka sojowego wykazała, że podjednostka alfa $7 \mathrm{~S}$ globulin soi zwiększa ekspresja receptora LDL ( receptora dla lipoprotein o niskiej gęstości) a także moduluje stopień sekrecji apolipoproteiny B przez hepatocyty. Prowadzi to do spadku syntezy cholesterolu oraz triglicerydów. Badanie białek nasion innych roślin strączkowych wykazały obecność podobnych peptydów. Analiza białka łubinu wykazała obecność 7S i $11 \mathrm{~S}$ globuliny czyli konglutyny alfa, beta i gamma. Ta ostatnia jest charakterystyczna tylko dla łubinu i jest oligomerem, który stanowi około 5\% całkowitego białka zapasowego w nasionach. Inna cechą różniącą białko łubinu od soi jest większa ilość wiązań polipeptydowych powstających po proteolizie $7 \mathrm{~S}$ globuliny łubinu. Peptydy białka łubinu słodkiego, podobnie jak peptydy wchodzące w skład białka soi, stymulują aktywność receptora LDL i wewnatrzkomórkowy metabolizm cholesterolu oraz odpowiadają za hipolipemiczne działanie białka słodkich odmian łubinu.

Dotychczasowe obserwacje pozwalają sądzić, iż białka nasion roślin strączkowych wykazują specyficzne właściwości hipolipemiczne. Należy również pamiętać, iż nasiona łubinu, w przeciwieństwie do nasion soi, jedynie w śladowych ilościach zawierają izoflawony, które przez wiele lat były uważane za główny czynnik odpowiedzialny za obniżenie poziomu lipidów osocza obserwowane u osób, których dieta jest bogata w produkty sojowe.

\section{Hipotensyjne działanie białka nasion roślin strączkowych}

Badania wskazują, że uwalniane podczas trawienia białek soi i najprawdopodobniej białek nasion innych roślin strączkowych krótkie peptydy hamują aktywność enzymu konwertującego angiotensynę, który katalizuje przemianę angiotensyny I do angiotensyny II (13). Obniżenie stężenia angiotensyny II prowadzi do zmniejszania oporu naczyniowego, poprawy funkcji śródbłonka a w efekcie do obniżenia ciśnienia tętniczego. Obserwacje kliniczne wskazują na hipotensyjne działanie diet bogatych w białko nasion strączkowych $(4,6)$. Wykazano, że regularne spożywanie białka soi oraz białka łubinu słodkiego wywołuje istotne obniżenie zarówno skurczowego jak i rozkurczowego ciśnienia krwi. Uważa się, iż białka te mogą odgrywać ważną rolę nie tylko w prewencji, ale także $\mathrm{w}$ dietetycznym leczeniu nadciśnienia tętniczego.

\section{Białka sojowe a nowotwory}

Badania epidemiologiczne pokazują, że w populacjach, w diecie których ważne miejsce zajmują produkty sojowe, stwierdza się niższą umieralność z po- 
wodu nowotworów prostaty, sutka, jelita grubego (14). W południowej Azji częstość nowotworów prostaty i sutka jest od 4 do 10 razy niższa niż w Ameryce Północnej. Spożycie białka sojowego w krajach tego obszaru waha się od $10 \mathrm{~g} /$ dzień w Chinach do 30-50 g/dzień w Japonii i na Tajwanie, podczas gdy w typowej diecie amerykańskiej jego średnia zawartość nie przekracza $3 \mathrm{~g} / \mathrm{dzien}$. Badania amerykańskie pokazały, że wśród mężczyzn spożywających regularnie białko sojowe ryzyko raka prostaty było o $70 \%$ niższe w porównaniu z mężczyznami których dieta nie zawierała tego białka.

Wykazano, że soja zawiera wiele substancji o potencjalnym antynowotworowym działaniu. Wśród nich ważne miejsce zajmują Bowmana-Birk’a inhibitory proteazy (7). Koncentraty bogate w to białko hamują aktywność enzymów proteolitycznych związanych zarówno $z$ inicjacją jak i rozwojem procesu nowotworowego.

Ostatnio uwagę badaczy przyciąga obecny w białku sojowym peptyd składający się z 43 aminokwasów nazwany lunasiną (5). Peptyd ten wykazuje właściwości antymitotyczne. Wykazano, iż umiejscawia się on w jądrze komórkowym. W przypadku prawidłowego rozwoju komórki przebywa w stanie „uśpienia”. Uaktywnia się w momencie, kiedy dochodzi do transformacji nowotworowej, a efektem jego działania jest śmierć komórki. Przypuszcza się, ze lunasina hamuje acetylację histonów a także przyłącza się do produktów ich deacetylacji. Zaburzenie procesu acetylacji/deacetylacji histonów prowadzi zaś do śmierci komórki. Wydaje się, że lunasina działa tylko na ściśle określonym etapie transformacji nowotworowej. Nie stwierdzono jej aktywności ani w zdrowych komórkach ani w dojrzałych komórkach nowotworowych. Sugeruje to szczególną rolę tego peptydu w zapobieganiu rozwojowi procesu nowotworowego. Dotychczasowe badania na zwierzętach wskazują, iż ponad 35\% doustnie przyjętej lunasiny jest absorbowane, dociera do tkanek i umiejscawia się w jądrach komórkowych. Dokładny mechanizm tych zjawisk jak i efektywność tak dostarczonego peptydu w hamowaniu transformacji nowotworowej zachodzącej pod wpływem różnych czynników wymaga dalszych badań. Nie wiadomo również czy peptydy o podobnym działaniu znajdują się w białkach innych roślin.

\section{Piśmiennictwo}

1. Anderson J.W., Johnstone B.M., Cooke-Newell M.E. Meta-analysis of the effects of soy protein intake on serum lipids. N. Engl. J. Med. 1995, 333:276-82.

2. Anderson J.W., Major A.W. Pulses and lipaemia, short- and long-term effect: Potential in the prevention of cardiovascular disease. Br. J. Nutr. 2002, 88, Suppl. 3: S263-\$271.

3. Arnoldi A. Grain legumes and the prevention of cardiovascular disease. In „Functional foods, cardiovascular disease and diabetes", ed. A. Arnoldi, 2004, CRS Press, Woodhead Publishing Limited, Cambridge England. 
4. Burke V., Hodgson J.M., Beilin L.J., Giangiulioni N., Rogers P., Puddery I.B. Dietary protein and soluble fiber reduce ambulatory blood pressure in treated hypertensives. Hypertension 2001, 38:821-6.

5. De Lumen BO. Lunasin: a canser-preventive soy peptide. Nutr Rev 2005, 63: 16-21

6. He J., Gu D., Wu X. Et al. Effect of soybean protein on blood pressure: a randomized, controlled trial. Ann. Intern. Med. 2005, 143: 1-9.

7. Kennedy Ar. The Bowman Birk inhibitor from soybean as an anticarcinogenic agent. Am J Clin Nutr 1998, 68 (suppl.6): 1406S-1412S

8. Lovati M.R., Manzoni C., Gianaza E., Arnoldi A.,Kurowska E., Caroli K., Sirtori C.R. Soybean protein peptides regulate cholesterol homeostasis in Hep 62 cells. J. Nutr. 2000, 130: 2543-49.

9. Manzoni C., Duranti M., Eberini M., Schamag H., Marz W., Castiglioni S., Lovati M.R. Subcellular localization of soybean $7 \mathrm{~S}$ globulin in hep 62 cells and LDL receptor up-regulation by its a constituent subunit. J. Nutr. 2003, 133:2149-55.

10. Nowicka $G$ et al. Assessing health claims for functional foods. In „Functional foods, cardiovascular disease and diabetes", ed. A. Arnoldi, 2004, CRS Press, Woodhead Publishing Limited, Cambridge England.

11. Nowicka G, Panczenko-Kresowska B. Hypocholesterolemic effect of grain legumes' proteins. Żyw.Czlow.Metab 2005, 32: 47-55 (in polish)

12. Nowicka G., Naruszewicz M., Klosiewicz L., Sirtori C.R., Arnoldi A. Lupin proteins in the treatment of hypercholesterolemia. XIV International Symposium on Atherosclerosis, Rome 2006, Abstract.

13.Wu J., Diong X. Hypotensive and physiological effect of angiotensin converting enzyme inhibitory peptides derived from soy protein on spontaneously hypertensive rats. J. Agric. Food Chem. 2001, 49: 501-5.

14. Wu AH, Ziegler RG, Nomura AM et al. Soy intake and risk breast cancer: in Asian and Asian Americans. Am J Clin Nutr 1998, 68 (suppl.6): 1437S-1444S

\title{
Vegetable proteins as functional food
}

\begin{abstract}
The primary role of the diet is to provide adequate quantities of nutrients to meet metabolic requirements and maintain optimal health. However, it has been shown that certain types of food or specific food components can affect a variety of body functions and provide specific health benefits. Diet containing such types of food may promote better health and play an important role in disease prevention by reducing the risk of certain chronic diseases. Vegetable proteins, especially legume proteins, have been recognized as factors influencing lipid metabolism. Hypocholesterolemic effects of different legume proteins have been documented. Hypotensive action of bioactive peptides derived from soy and lupin proteins has been reported. In soy a peptide of anti-mitotic activity was found and it may play a significant role in suppression of tumor development and cancer prevention. Diet rich in vegetables and vegetable proteins is related to lower risk of cardiovascular and cancer mortality.
\end{abstract}

